Rowan University

Rowan Digital Works

2015

Queering the teacher as a text in the English language arts classroom: Beyond books, identity work and teacher preparation

Kate E. Kedley

Rowan University, kedley@rowan.edu

Follow this and additional works at: https://rdw.rowan.edu/education_facpub

Part of the Language and Literacy Education Commons

Recommended Citation

Kedley, K. E. (2015). Queering the teacher as a text in the English language arts classroom: Beyond books, identity work and teacher preparation. Sex Education: Sexuality, Society, and Learning, 15(4), 364-377.

This Article is brought to you for free and open access by the College of Education at Rowan Digital Works. It has been accepted for inclusion in College of Education Faculty Scholarship by an authorized administrator of Rowan Digital Works. 


\section{Queering the Teacher as a Text in the English Language Arts Classroom: Beyond Books, Identity Work, and Teacher Preparation}

Abstract: Classrooms reflect and contribute to normative sex, gender, and sexuality categories in school culture, rules, and rituals. Texts, materials, curriculum, and the discourse we employ as educators perpetuate the pervasiveness of these categories. This article explores the less visible ways sex and gender categories are constructed in English Language Arts (ELA) classrooms, and how institutionalized heteronormativity positions students within normative categories of sex, gender, and sexuality. These limiting conversations are difficult to identify and even more difficult to challenge. But it is precisely this dynamic - the subconscious reinforcing of sex and gender binaries - that upholds the dominance of the institution of heterosexuality. Merely addressing LGBTQ issues in the field of teaching reading, writing, and literacy is an incomplete strategy. I argue that to disrupt normative narratives in the ELA classroom, educators must first identify the everyday practices occurring in school spaces, specifically recognizing the teacher as a text. For sustained challenges to institutionalized norms, ELA teachers must engage in this work outside of LGBTQ-inclusive instructional materials and anti-homophobic education, and I offer specific methods for disrupting mainstream narratives in ELA classrooms.

Keywords: gender; sexuality; queer; English Language Arts; heteronormativity; LGBTQ

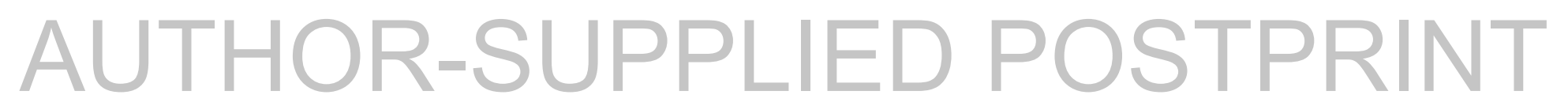


The increased visibility of LGBTQ (lesbian, gay, bisexual, transgender, queer) issues in media, legal spheres, and contemporary US society has been met with the vigorous response of researchers. Building on existing pedagogical, secondary English Language Arts (ELA), and LGBTQ research, I suggest teachers view themselves as texts in the classroom and work to queer readings of themselves as they might do with traditional ELA texts. Queer scholars have theorized that heterosexuality as a dominant sexuality is dependent on a clear-cut and nonoverlapping sex and gender binary (Butler, 1993), and a system of heteronorms. The sex and gender binary and the system of heteronorms are pervasive in schools, and are endorsed in subtle ways by teachers. Identifying and disrupting the binary and heteronorms challenges normative configurations of sexuality in the everyday spaces of ELA classrooms. I begin by outlining the fundamental aspects of queer theory and queer pedagogy that influence my analysis. Then I explore recent scholarship on gender and LGBTQ issues in ELA classrooms. I build upon existing research by suggesting that to disrupt normative narratives, educators must identify the everyday practices occurring in school spaces that support them, and engage in this work outside of LGBTQ-inclusive instructional conversations, texts, materials, and curriculum. I conclude by offering practical methods of disrupting mainstream narratives in ELA classrooms.

\section{Defining Concepts Relevant to Queering Everyday Spaces of the ELA Classroom}

Though queer theory is not one unified field of study, there are a number of components I employ in this analysis that influence my understanding of the social and personal categories of sex, gender, and sexuality. The use of queer theory and queer pedagogy for this analysis was deliberate. LGBTQ-inclusive and anti-homophobia or anti-bullying models create safe spaces and ensure sufficient LGBTQ representation in the short stories, novels, and conversations of the ELA classroom. Additionally they allow teachers who identify as straight to position themselves 
as LGBTQ allies. These models have a number of limitations. First, LGBTQ students are actively positioned as a minority 'other', which keeps the hetero-homo binary intact (Britzman \& Gilbert, 2004; Lovaas, Elia, \& Yep, 2006; Sedgwick, 1990). Second, focusing on students who identify as LGBTQ is a distraction from structural oppressions like homophobia and homophobic people (Blackburn \& Smith, 2010; Macintosh, 2007). Unwillingness to engage with LGBTQ themes in the classroom is framed as a 'limit of attitude' (Britzman, 1995, p. 160) and changing teachers' and students' attitudes about LGBTQ issues becomes the focus rather than understanding how these hierarches are constructed and how to challenge them. Finally, these models assume students to be a homogeneous group that shares a common experience (i.e. having a minority sexual or gender identity) (Blackburn \& Smith, 2010). Race, class, religion, language, nationality, age, and other social categories that intersect with gender and sexuality and affect the lived experiences of students are brushed over in favor of commonalities (Parent, DeBlaere, \& Moradi, 2013). LGBTQ-inclusivity and ally-ship have been integral in challenging homophobia and fostering acceptance in classrooms. However, considering the continued stigma of sexual or gendered minority identities, these models have limitations that can be complicated by a model based in queer pedagogy.

A model based in queer theory shifts the focus from LGBTQ students to all students. Sex, gender, and sexual identity categories are often thought of as 'stable, coherent, and reasonable', but queer theory suggests these categories are 'messy, slippery, and always in flux' (Ryan \& Hermann-Wilmarth, 2013, p. 145). A queer theoretical lens doesn't position or identify students as LGBTQ or not, and students aren’t grouped into a homogenous category separate from other identities, such as race or class. Sex, gender, and sexuality in individuals are seen as flexible rather than permanent, and recognizing their temporal nature 'has the potential to trouble 
the entire set of [gender and sexual identity] relations' (p. 147). A queer pedagogy framework addresses multiple oppressions in a complex network of hierarchies.

Two specific elements of queer theory support my argument. First, the relationship between sex, gender, and sexuality are not naturally linked (Butler, 1990; 2004) even though we often perceive them as such. A person assigned female at birth is not inclined to be feminine any more than masculine (or heterosexual, or homosexual). A person who is masculine is not more suited to heterosexuality than homosexuality, and their masculinity does not stem from their assignment at birth of male or female. Gender appears to naturally stem from assigned sex, but the presumed link is influenced by social constructions of feminine and masculine.

Second, sexual identities change over the course of a lifetime, from generation to generation, and from context to context. There is no true sexuality to be 'discovered' and students do not come to classrooms with predetermined and inherent sexualities, and this is equally applicable to sex and gender (Butler, 2004; Foucault, 1980). Hierarchies reinforce these seemingly permanent and naturally existing binaries. However, they 'are never quite carried out to expectation' (Butler, 1993, p. 229). The sex and gender binary is the social classification of people into two categories: either male or female (sex) and either masculine or feminine (gender) (Gilbert, 2009). In the binary, male is linked with masculinity, female is linked with femininity, and male-masculine and female-feminine are seen as naturally occurring and distinctive opposites. Disruptions to the binary are seen as temporal or unnatural (if somewhat accepted) outliers (Butler, 1990). Even when female masculinity or male femininity is accepted culturally, it is regarded as secondary to the default 'natural' categories that are female-feminine and malemasculine. Heteronorms are legal and cultural norms that use the binary to make heterosexuality appear as the only legitimate option for coupling, dating, and relationships. Besides legal 
restrictions on access to marriage or to the agency to define one's own sex or gender, cultural examples include forms listing a 'mother' and a 'father' and the assumption that children are heterosexual from a young age (i.e. calling a baby boy a 'lady's man'). These heteronorms make non-normative sexual relationships or gender identities invisible, undesirable, and in some places, illegal. Few of us have lived experiences that consistently meet the current cultural ideals of female/male, feminine/masculine, or heterosexual/homosexual during every single moment of our lives. To queer something, then, asks questions about 'the taken-for-granted assumptions we make about categories and the supposedly stable relations among them' (Piontek, 2006, p. 2). I suggest ELA teachers should recognize the limitations of allied stances and text inclusivity and actively queer their presence as a text in the classroom. Rather than be limited by dichotomous views of gender and sexuality, teachers can make themselves and their lives less readable as a text with a sex, gender, and sexual identity, and less intelligible by not validating those normative categories. ELA teachers are a human presence at the front of every classroom. Besides choosing texts, providing writing activities, and marking assignments, ELA teachers provide a gendered and sexual identity in the front of every classroom which is read daily by students. Because of this, teachers should identify, question, and disrupt the subtleties of heteronorms as they themselves perpetuate them in the everyday spaces of schools.

Further justification for queering the teacher-text lies in the fact that heteronormativity supports other normative notions of race, class, religion, and nationality. When the central objective is working against homophobia and heterosexism, the work operates 'within normalizing discourses that reify a white, masculinist, middle class bias' and are simplistic and reductive (Fox, 2007, p. 500). Oppression should be understood as less of a simplistic attitude problem (based on individual identities) and more as a result of socially constructed and unequal 
relationships. This system of power also upholds the dominance of the political category of whiteness, normalized family structures, and patriarchal and middle-class values. The subversion of gender and sexuality norms must recognize that minority gender and sexual identities are not one unified entity (and neither are normative gender and sexual identities). It is imperative to interrupt gender and sexuality norms in ways that disrupt (in ways that don't reinforce) the political categories of whiteness, class, religion, nationality, and family, etc. (see Fox, 2007).

\section{Existing Research: The English Language Arts Classroom and LGBTQ Themes} Current explorations of LGBTQ themes in secondary ELA classrooms center on four areas: (1) offering opportunities to understand sexual identity through reading and writing, (2) using texts (generally books) that expose students to LGBTQ themes to foster tolerance, (3) preparing teacher educators at the university level, and (4) analyzing teachers' viewpoints on working with (or rejecting) LGBTQ themes in the classroom. Below, I summarize the four areas and studies representative of each, and follow with a brief commentary on gaps in the research.

\section{Identity Work - Understanding Sexual Identity through Reading and Writing}

In a literacy classroom 'youth who do not fit into the mainstream are more likely to sanitize their reading, writing, and discussion choices' (Moje \& MuQaribu, 2003, p. 206) especially around issues of sexual identity or orientation. Literacy classrooms, then, can also be limiting for students in terms of sexual identity exploration, especially if their exploration is not heteronormative. A student's sexuality 'might shape his or her interpretation of a story about heterosexual love and marriage' because marginalized students are positioned differently relative to the story than their peers (Vetter, 2010, p. 100). But because language use is inherent to ELA classrooms, reading and writing have the potential to disrupt dominant discourses and can offer students opportunities to explore sexual identities. Literacy educators can and should provide 
assignments that allow students to explore their identity, and 'push for spaces that provide opportunities for students to navigate marginalized identities in schools' (p.101).

The articles on identity work assume students come into ELA classrooms with a predetermined sex, gender, or sexuality and only students with a minority sex, gender, or sexuality need support in exploring those identities through reading and writing. Presumably heterosexual students are generally not assumed to need space to explore, although queer students explore their sexual identity in the journey of coming-out. Mayo's (2013) article examines the identity of the 'straight' students in a secondary school Gay-Straight Alliance (GSA), but in terms of their identity as an 'ally'; straight allies explored their identity as a member of the GSA (but, notably, not their heterosexual identity) and how to 'support LGBTQ peers, while defending their potentially unpopular decision to do so' (p. 268). Identity work stops short of allowing heterosexual-identified students the opportunity to explore their sexuality and gender, and Moje and MuQaribu (2003) suggest it should only come up if students choose to explore it themselves.

\section{LGBTQ Texts in the ELA Classroom}

Texts are suggested as a way to engage students with LGBTQ themes, foster tolerance, and combat homophobia in classrooms. All children should have access to books at school that are 'reflective of their cultures' (Smolkin \& Young, 2011, p. 217), including non-normative family structures. Teachers should update their classroom resources to meet the needs of their students. However, the inclusion of LGBTQ texts in a classroom does not go far enough (Banks, 2009, Blackburn \& Smith, 2010). Because many of the books with queer-identified characters center on the character's 'struggle' or learning to 'deal with' their sexuality, texts like these can be reductive when they occupy the entire canon of queer literature and reinforce the idea that one's 
sexuality (especially one's minority sexuality) is 'inherently controversial and conflicted' (Banks, 2009, p. 35).

The inclusion of LGBTQ texts in classrooms frames minority sexual and gender identities as the 'other' and does little to encourage students who occupy dominant sexuality and gender categories to question their own position within these terms. Adding these texts 'to combat homophobia without addressing the ways that heterosexuality is constructed as normal does little to redress unequal power relations and privilege associated with sexual orientation and gender identity' (Schieble, 2012, p. 207). If homosexuality and heterosexuality are presented as binary opposites with no possible overlap, the hierarchy is reinforced rather than disrupted when LGBTQ texts are offered without critical support.

\section{Teacher Preparation and Exposure to LGBTQ Issues}

Pre-service teaching programs are another space in the effort to engage with LGBTQ issues in the classroom. Creating 'safe spaces for teacher candidates to interact with members of the LGB community' can provoke positive change in their attitudes (Larrabee \& Morehead, 2010, p. 39), and these teachers should be given the opportunity and the space 'to honestly engage in dialogue about controversial, even belief-challenging topics,' so they become more adept at understanding complex issues (Hermann-Wilmarth, 2010, pp. 196-197). Specifically linking lesbian and gay issues with social just issues allows for a positive 'shift in [pre-service teachers'] dispositions' toward lesbian and gay students in schools (Anthanases \& Larrabee, 2003, p. 256).

These studies suggest that exposing pre-service teachers to LGBTQ literature and issues has potential in influencing school culture and classroom content. Macintosh (2007) 'recognizes the dangers of this method' (p. 33), that exposure to LGBTQ themed literature is a 'tidy solution' (p. 41) to heteronormativity or homophobia. Limitations include ignoring heteronormative 
dominance, and assuming that 'the teacher has no difficulty... responding with generosity' (Britzman \& Gilbert, 2004, p. 84) when presented with opportunities for LGBTQ inclusion or tolerance. An important component of teacher education is ample time and space to practice disrupting normative gendered and sexual (and racial, and classed) identities (HermannWilmarth, 2010), and exposure through discussion, texts, in-services, guest lectures, and panels alone are unlikely to prompt change. Payne and Smith (2012) suggest that '...teacher education programs need to integrate issues of gender and sexuality throughout their programs of study' more widely (p. 238).

\section{Teachers' Reluctance in Engaging with LGBTQ Themes}

Teachers in ELA classrooms often have difficulties 'responding with generosity' (Britzman \& Gilbert, 2004, p. 84) and are reluctant to engage with LGBTQ themes in a classroom. In an online discussion board for a university teaching course, teachers suggested the ELA classroom was not an appropriate place to address LGBTQ issues. Students were willing to stand up to overt homophobia (i.e. addressing the use of gay slurs), but otherwise resisted including LGBTQ themes or critical discussions of sexuality or gender (Thein, 2013). Schieble (2012) had similar conclusions, and noted that the "resulting apologies, hedges, and diffusions maintained an 'impasse of niceties that mediated any real critical engagement' with the issue of LGBTQ themes in a classroom (p. 219). In other pre-service teacher training, students 'appeared to silence and avoid LGBQ topics' and some 'actively repeated harmful messages and generally blocked student attempts to disrupt the dominant discourse' (Puchner \& Klein, 2011, p. 236).

These studies highlight the ineffectiveness of simply exposing pre-service teachers to LGBTQ themed materials, texts, panels, and discussions. Britzman notes that inclusion of LGBTQ literature in the curriculum is not sufficient to disrupt heteronormativity, and instead, 
teachers should look for ways to consider the 'limits of one's own thinking' and our tendency to place gender and sexualities into opposing binary categories (as cited in Schieble, 2012, p. 220). The use of LGBTQ texts along with discussions of normativity would be more effective in prompting teachers to consider LGBTQ themes in their classrooms. Thein (2013) suggests having teachers analyze their language use in their explanations of resistance, which may draw out the faulty logic of their discourses and complicate their reluctance (p. 177).

Based on the scholarship of ELA and LGBTQ themes, and the limitations outlined above, queer theory as a model has the potential to prompt teachers to complicate their unintended validation of heterosexuality and normative gender categories, and literacy scholars should seek and create opportunities to document situations when teachers and students are making 'gender trouble' (Blackburn, 2005, p. 414). I suggest queering the teacher as a text in the classroom to build on the exiting research in LGBTQ and ELA education. In addition to traditional texts, and spaces such as hallways and offices, which can also be read as a text (Fox, 2007), Clark (2010) suggests the teacher is a text in the classroom: 'As I consider textual practices in teacher education, I cannot deny the presence of myself as a text' (p. 705). To consistently trouble notions of gender and the teacher as an ally is to create a 'truly' just, equitable and safer space for LGBTQ young people in schools (p. 712). Through close examinations of language use, purposeful ambiguity, and risk-taking, the teacher as a text in the classroom can disrupt normative narratives of sex, gender, and sexuality.

\section{Validating Normative Sex, Gender, and Sexuality}

A brief discussion of legal and cultural heteronorms and their permeation in the ELA classroom will help teachers understand their complicity in maintaining heterosexual dominance, and supports my argument that teachers recognize themselves as a text in the classroom. Challenging 
normative narratives in school and classroom settings cannot be accomplished unless these narratives are first acknowledged. Because these narratives are often so naturalized, they are also often invisible.

Legal heteronorms are rules and regulations that maintain the sex and gender binary and heterosexual dominance. At the time of writing, more than thirty states in the US allow same-sex marriage; in early 2004, there were zero. A few years ago no one could openly identify as homosexual and simultaneously serve in the US military (Don't Ask, Don't Tell was the official policy until 2011). In some states LGBTQ-identified people cannot legally adopt children and can be fired from a job for identifying as such. It is legally difficult, if not impossible, to alter the sex assignment one is given at birth, and for people who identify as transgender, this can be difficult and even dangerous.

Cultural heteronorms also affirm the naturalness of the sex and gender binary and heterosexuality. It is common for married heterosexual couples to refer to their husband or wife highlighting not just their relationship status as legally coupled, but also their sexuality by stating the gender of their partner, and solidly positioning themselves within the dominant heteronormative narrative. Heterosexual relationships are validated in everyday conversation, both in the attention given to the relationship itself ('How is your husband?' 'When will you two start a family?'), and the level of comfort people in heterosexual pairings have to speak about their relationship in social settings.

\section{Linking Normative Sex, Gender, and Sexual Identity Categories and the ELA Classroom}

Sex, gender, and sexuality are often conceptualized as individual issues that are 'private matters... [however], they are highly influenced by social structures' (Pascoe, 2007, p. 10) and

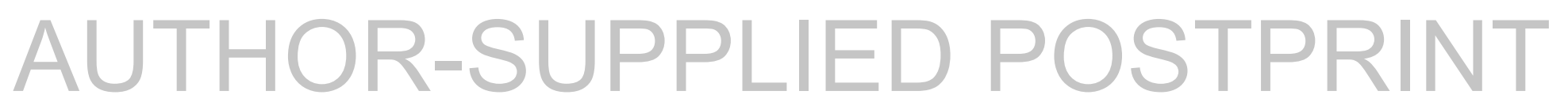


the schools are a structure that reflect and contribute to this dynamic. As I detail below, schools already actively endorse sex, gender, and sexual identity categories, albeit the dominant ones.

Gender differences are so naturalized that nearly all of our interactions are controlled by our perceptions of another's gender; if one's gender is confusing or ambiguous, we are rendered 'incapable of interacting and at a loss as to how to communicate' (Gilbert, 2009, p. 93). The practice of assigning sex at birth (based on genitals) results in 'expectations, limits, and roles' (p. 96) that accompany one into the school and classroom. We don't know others' genitals before we determine their sex or gender, but their gender expression (clothing, hair length and style, facial hair, makeup, etc.) provides us with signs we use to categorize people and interact with them. In ELA classrooms, these markers influence what books students read (Cherland, 1996; Dutro, 2001), how students are partnered for projects, and how students might conceive of themselves relative to their peers (girls act as other girls act, and in opposition to how boys act) (Lewis, 1999; Thorne, 1993). Blackburn and Buckley (2005) suggest that this doesn't only affect minority sexualities negatively; 'straight' students are also affected pedagogically in that they learn that LGBTQ people aren't worth mentioning in literature or ELA spaces.

Legal and cultural heteronorms inevitably spill over into the regulation of everyday spaces of schooling and ELA classrooms. The bullying of gender non-conforming students and those who are perceived to be gay is well-documented (Miller, Burns, \& Johnson, 2013). However, coercing, teasing, and a preference for clear gender expression is also subconscious and invisible; teachers don't necessarily force students in normative gender categories knowingly, students often willingly align themselves with the gender they were assigned at birth, and the teasing is sometimes subtle enough that one would hardly recognize it as such (Cherland,

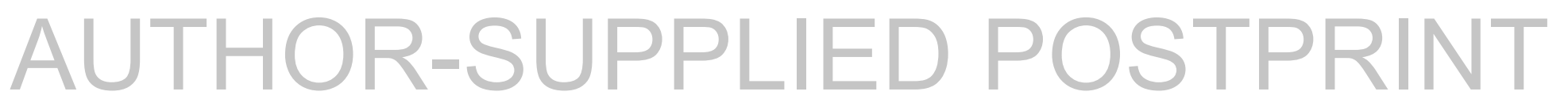


1996; Lewis 1999). Eyebrow raises, dismissive comments, and validations of 'normal' go a long way in promoting normative sex, gender, and sexuality categories.

One way coercion occurs is through the segregation of gender on all levels and 'the separation of girls and boys in friendships and causal encounters' (Thorne \& Luria, 1986, p. 178). When students cross the sex and gender binary they are policed by rules, bullying, discomfort, and teasing. Heterosexual pairings are also sanctioned in schools in the form of school dances or athletic teams, 'boy' and 'girl' groups or weekly leaders, and the use of texts, materials, curriculum, and spaces that are labeled as 'for girls' and 'for boys' (Pascoe, 2007). A student cannot occupy both categories simultaneously, or one category partially.

Heteronormative pairings are closely linked with sexuality and the act of physical sex. Boys and girls often self-segregate their friendships (in playground or lunchroom settings, choosing partners for group work, etc.) in what appears as a natural social division between boys and girls (Thorne \& Luria, 1986; Thorne, 1993). These friendships are heavily monitored, and gender norms in elementary schools 'lay the foundation for the more overtly sexual scripts of adolescence and adulthood' (Thorne \& Luria, 1986, p. 176). A common playground chant sings that two children are 'sitting in a tree, K-I-S-S-I-N-G'. The rhyme suggests the friendship will eventually result in sexual activity and the birth of a child, or the 'baby in the baby carriage'. Boy-girl friendships result in teasing and assumptions of dating from peers (p. 186), or perceptions of dangerous sexual possibilities from adults, and are overtly linked to heterosexualized behavior. Policing this highlights the difference between the genders; the relationship appears hetero-sexualized because of the difference in gender of the pair and the potential for what that means sexually.

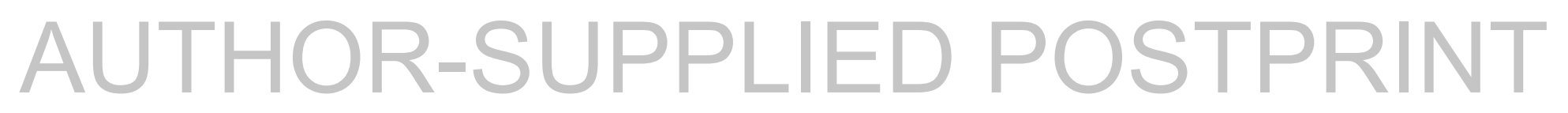


Because gender and sexuality so closely inform and are reflected in our schools, what does this mean for the ELA classroom? Should our goal as educators be to do away with gender, or the sex and gender binary? Should we provide more support for gender non-conforming students, or create spaces for students to play with their own gender identities? Once these categories are sufficiently complicated, how do we keep the categories of male, masculine, and heterosexual from resurfacing as dominant? How do we complicate sex, gender, and sexual identities while recognizing intersectional identities? Heteronormativity - which stems from strict regulation of a sex and gender binary system - makes 'teaching about same-sex, lesbian, bisexual, gay and queer sexualities a fraught, rather than joyous' topic to engage with in school settings (Sykes, 2011, p. 424). Enforced by everyone from lawmakers to peers, sex and gender are separated into two clear-cut and non-overlapping categories. Heterosexuality as the dominant sexuality depends on this.

\section{Disrupting Heteronorms in the ELA Classroom: Three Ways to Queer the Teacher-Text}

Making the legal, cultural, and educational heteronorms visible illustrates the pervasiveness of the gender binary and heteronormativity in the social and institutional practices of schooling. Such practices cannot be disrupted in the ELA classroom through the inclusion of LBGTQ texts and discussions, or acknowledgment of LGBTQ identities. In fact, these efforts may reinforce the binary and continue to support the political categories of whiteness (Fox, 2007) and middle class values. Drawing on queer theory, I offer a framework for ELA teachers to move toward radical disruption of unintended heteronormativity in their classrooms. I suggest teachers: (1) view themselves and their language as a teacher-text in the classroom, and carefully examine how they are 'read' and what messages they send both overtly and subversively; (2) queer themselves as a teacher-text through ambiguity; and (3) engage in risk-taking. These 
considerations are a challenge to teachers who use LGBTQ-inclusive education whether they identify as LGBTQ or not, and those who claim to be LGBTQ allies. All teachers - regardless of gender or sexual identity - are complicit in and contribute to mainstream narratives in their classrooms. Teachers who claim LGBTQ ally status often end up 'posturing identities that appear inclusive in their language yet are careful to protect their dominant heterosexual status' (Vavrus, 2009, p. 385) in other ways. Queer-identified teachers are not exempt from the need for examination of their language use and presence in a classroom. Complicity is often unintentional, but the validation of normative styles, behaviors, and discourses communicate what is accepted and normal to students, and what is not. This model's strength is that it encourages all teachers and students to pinpoint their complicity in sex, gender, and sexuality oppression, and to adjust their presence in the classroom in ways that don't subconsciously reinforce the dominant sex, gender, and sexuality narratives in ELA classrooms.

\section{Recognizing the Teacher-Text}

Teachers are texts (Clark, 2010) that are 'read' by students in casual conversations, methods of taking attendance, greetings in the hallway, and presence at extra-curricular activities. Perhaps more influential than novels or short stories, teachers are highly visible and ever-present texts at the front of every classroom. This 'reading' occurs in obvious ways (lecturing and how to achieve a good grade) and subtle ways (how a professional looks, and the importance of having a favorite sports team). In this section, I will refer to the teacher as a text as the 'teacher-text'.

Consider what is at stake in heteronormative readings of the teacher-text by the student. What message does the teacher-text send about race, class, religion and other social categories vis-a-vis heteronormativity? Sykes (2011) links heteronorms directly to 'racialization, or from histories of colonialism and nation formation' (p. 429) and heteronorms are framed in white, 
middle-class, monogamous narratives (Fox, 2007; McNeil, 2013). Noting legal marital status sends a multiplicity of messages about values and religion, even if one is not religious - this teacher supports the institution of marriage and believes in permanent and monogamous relationships (regardless of whether lived experiences reflect that). The heteronormative narrative simultaneously supports religious, racial, and classed oppression. Recognizing complicity in heteronormativity involves recognizing complicity in a network of norms (Jacobsen, 1998, p. 520). Teachers who consider themselves against all forms of oppression must consider how their complicity with heteronormativity supports race, class, and religious hierarchies.

Hermann-Wilmarth and Ryan (2013) call for research that looks for 'all of the places where heterosexuality is... already in schools' (p. 229). ELA teachers who support LGBTQ issues and include LGBTQ students' experiences in their classrooms should not overlook their own powerful presence in the classroom. I suggest queering the teacher-text within three areas of consideration: uncovering heteronorms, ambiguity and ambivalence, and risk.

\section{Queering the Teacher-Text - Uncovering Heteronorms in Language Use}

First, ELA teachers must consider what students read between the lines of the teacher-text. Queering something asks questions about 'the taken-for-granted assumptions we make about categories and the supposedly stable relations among them' (Piontek, 2006) and asking what messages are sent to students 'between the lines'. Teachers may not realize the 'extent of homophobia and their complicity in it... [until they begin] talking about' it more extensively (Blackburn \& Smith, 2010, p. 235) and close examination of language use through self-reflection and critique can uncover areas where teachers are perpetuating heteronorms. Queering the teacher-text asks teachers for vigilance in destabilizing their complicity. Inherent in these 
examinations is a power analysis: Who does it serve to treat boys and girls differently? How is heterosexuality framed as the 'normal' and 'natural' way of being? How do all teachers (queerand straight-identified) contribute to this?

When I was a student, the (boys') football team was widely celebrated and girls' teams were referred to as uniquely female (the Tennessee Lady Volunteers, or the Raiderettes). Single teachers, regardless of age, were suspected of being sexually promiscuous or gay. LGBTQ personalities were the subjects of jokes, gagging sounds, and eye rolls, and variations in gender or sexuality were quickly coerced into mainstream categories with sidelong glances, admonitions, and dismissals. LGBTQ issues were considered private while heterosexual families very publically celebrated their own private life - weddings, pregnancies, and dating. These experiences were so naturalized I rarely suspected they weren't the natural order of things. I didn't have the language to challenge how these assumptions played out on my behavior.

Policing and regulation of sex, gender, and sexuality was not unique to my experience. No one fulfills the cultural expectations for these idealized categories, but strict regulation (from teasing to rules) is used by society and institutions to position people into the categories. 'To the extent that gender is an assignment, it is an assignment which is never quite carried out according to expectation' (Butler, 1993, p. 231) and very few people approximate the ideal even as we simultaneously resist and embrace it. To destabilize complicity in heteronormativity, ELA teachers should first look for how they unwittingly validate heterosexuality and gender norms through language use. Teachers can ask: How do I actively position myself, as the teacher-text, as close to the ideal as possible? Where do I embrace heterosexuality, masculinity, and whiteness in myself and in others? What purpose does this serve to maintain heterosexual dominance? Where can I more honestly represent deviations from the norm? 
An ELA classroom, where language is the main subject, a lesson about pronouns could ask students to count how many times in an hour they inadvertently point out someone's gender - he, she, him, her - to highlight the prevalence of gendering in everyday language and literature. Students could list their favorite books and as a class tally: how many have lead male characters, lead female characters, and primarily heterosexual relationships? What assumptions are made about characters' sexualities and genders? Why are these books their favorite? What stories are students embracing, and what narratives are students not as fond of, and why?

Because of its naturalized status, our use of language has implications for what students understand as normal in classrooms. This discourse of normalcy unveils our deeply-embedded understandings of sex, gender, and sexuality; we can rarely see the sexed, gendered, and sexualized nature of our language without being prompted. A lifetime of assumptions about gender and sexuality isn't overtly homophobic; it does however make homosexuality or gender variance an invisible non-option for many students, and should be closely examined in ELA classrooms through a study of language use.

\section{Queering the Teacher-Text - Ambiguity and Ambivalence}

Ambiguity is ever-present in the ELA classroom, from discussions of literature to individual student writing activities. One place this potential for ambiguity may not be acknowledged is in terms of gender and sexuality. Gilbert (2004) suggests that ambiguity in literature can serve as a "vagueness that pushes against the limits of language (p. 239) that limit how we can understand and talk about gender and sexuality. Butler (1990) suggests that genders are readable when they conform with 'recognizable standards of gender intelligibly' (p. 22) and if someone's gender isn't immediately clear, we aren't sure how to interact with them. We categorize ambiguity as quickly as possible in normative ways that erase uncertainty (Gilbert, 
2009). Classrooms provide categorization so we can all be read 'appropriately': students' genders are made readable by official school records, use of first names, or participation on a sports team. Queering the teacher-text suggests teachers explore how resolving unintelligibility and ambiguity work to regulate sex, gender, and sexuality.

When I taught elementary students, the youngest students called me 'Mr. Kate' and asked: 'Mr. Kate! Are you a boy or a girl!?' A student referred to me as 'him' and argued with another who said I was a 'mom'. If I responded in ambiguous terms the students would return to their jump ropes or soccer balls and let the uncertainty stand. However, nearby adults were quick to 'correct' the students, reminding them I was 'Ms. Kate' and resolving the issue by placing me clearly and permanently on one side of the sex and gender binary. Ambiguous sexuality is also carefully scrutinized. To be intelligible, we mark ourselves: 'I'm not gay, but I find Marilyn Monroe so attractive...'; 'I'm a proud LGBTQ-ally'; 'No, I don't have a boyfriend'; and 'My wife and I are starting a family'. Although we often claim sexuality is a private matter, heterosexuality is very clearly not, and unreadable heterosexuality risks being categorized as homosexuality or queer. To prevent that, these comments make (hetero)sexuality (and even sexual activity, like 'starting a family') a very public matter. Is it necessary to state for example, in one's support for gay rights, one's own status as not gay? Is there a reason people must identify the gender of their partner (husband or wife)? What purpose does readability serve?

If people can't be placed neatly into one side or other of the sex, gender, and sexuality binary, gendered names, bathrooms, clothing, hair, and other cues appropriately position them as quickly as possible. I suggest that 'ambivalence... can become the site for agency, for iterating the norm differently (Jakobsen, 1998, p. 526). How does intelligibility work to support the binary, and how could ambivalence and ambiguousness work to disrupt it? We proclaim matters 
of sex, gender, and sexuality as private issues, so why must we clarify (especially normative) sex, gender, and sexuality at every opportunity? Do sex, gender, and sexuality have to be centered in all of our actions and all of our conversations? In a practical sense, is there a way that a teacher who identifies as heterosexual can be a queer 'ally' without reaffirming their heterosexuality in the label? Can they talk about families and relationships without unwittingly endorsing and validating the 'hetero' part? In ELA classrooms, literature can be used to explore how gender and sexuality markers make characters ambiguous or readable (Thein \& Kedley, in preparation), and writing activities can offer opportunities to examine constructions of gender and sexual identity in narrative form. Validation of normative categories works at the expense of marginalized identities, and ELA teachers and classrooms, using literature and writing activities, can serve as a space for critique.

A caveat: there is a hierarchy within sex, gender, and sexual identities, and many face discrimination, subtle and overt, because of their sex, gender, or sexual identity. All teachers, regardless of identity, validate normative categories: they may talk about their own heterosexual lives, ask about others' heterosexual lives, and make accommodations for both. Rather than claiming minority sex, gender, or sexuality status (unless one identifies as such), I suggest that teachers simply not automatically reinforce their dominant sex, gender, and sexuality status and allow those categories to be destabilized by making them less intelligible and therefore less validated. This effort focuses on finding ways to acknowledge heterosexuality that doesn't simultaneously oppress, discriminate, or ignore minority identities, or looking for ways to validate minority sex, genders, and sexualities. A muddling of the self and the other, the hetero and the homo, and a decentering of sex, gender, and sexuality from how we function as teachertexts can work to disrupt oppressive discourses. 


\section{Queering the Teacher-Text - Risk}

In their provocative article 'Queering Public School Pedagogy as a First-Year Teacher', Krywanczyk (n.d.) asks: 'What good does it do to encourage students to challenge racist and bigoted conventions of beauty... when every adult in the building visibly tries their hardest to adhere to those standards of attractiveness?' (p. 79). Krywanczyk's question prompts another: What good is it to be an LGBTQ ally when there is so much effort to reinforce one's dominant sex, gender, and sexuality status? Queering the teacher-text suggests teachers exceed the limits of their students' understanding of what women and men, feminine and masculine, and gay and straight are. This involves risk-taking by challenging the centrality of sex, gender, and sexuality in our lives.

Adkinson and DePalma's (2008) study of university students in education notes that 'even the simplest of anti-heteronormative actions' were seen as 'brave and radical acts'.

Heteronorms were so prevalent in classrooms that students thought 'even the mere mention of an alternative [was] transgressive to the point of being dangerous' (p. 32). Bringing an LGBTQthemed book into the classroom or calling oneself an ally was considered to be a great risk. What type of risk would it take to exceed our current understandings of sex, gender, and sexuality? What type of risk would it take to shift our current understandings of families, of couples, and of relationships?

Educators aware of heteronormative privilege also feel the 'discomfort that this knowledge creates' (Macintosh, 2007, p. 40). I suggest that queering the teacher-text should involve discomfort and risk-taking. The risk may seem mundane: What personal risk do I take if no one knows I'm officially married? What risk do I take if I call my girlfriend my partner, rendering my sexuality less readable? What risk do I take if I ask my students to critique sex, 
gender, and sexuality in literature, and explore it in writing? Opening students' eyes to heterosexual and gendered oppression facilitates the opportunity for students to contribute their own ideas and discoveries about the role sex, gender, and sexuality play in their lives.

Self-reflection about language use, ambiguity, and risk-taking about representations of sex, gender, and sexual identity categories encourages ELA teachers and students to examine the 'normalness' of these binaries, and identify places where they don't hold true. Few teachers meet the ideal standards for sex, gender, and sexuality in the first place, and I suggest not actively endorsing when we meet these standards, and recognize when we and others don't in a way that doesn't create an 'othered' category. The ELA classroom, especially, is a relevant place to actively queer the teacher-text, in that ELA teachers already work with texts, activities, and curriculum that allow for that flexibility. All ELA teachers, regardless of sexuality, can queer normalized discussions of sex, gender, and sexuality in classrooms. This may seem like a vulnerable and personal risk. However, teachers must exceed the limits of their own understandings of sex, gender, and sexuality in order to exceed the limits of their students' understandings. 


\section{References}

Adkinson, E. and DePalma, R. 2008. Imagining the Homonormative: Performative Subversion in Education for Social Justice. British Journal of Sociology of Education 29(1): 25-35.

Anthanases, S. Z. and Larrabee, T. G. 2003. Toward a Consistent Stance in Teaching for Equity: Learning to Advocate for Lesbian- and Gay-Identified Youth. Teaching and Teacher Education 19: 237-261.

Banks, W. P. 2009. Literacy, Sexuality, and the Value(s) of Queer Young Adult Literatures. English Journal 98(4): 33-36.

Blackburn, M. 2005. Disrupting Dichotomies for Social Change: A Review of, Critique of, and Complement to Current Educational Literacy Scholarship on Gender. Research in the Teaching of English 39(4): 398-416.

Blackburn, M. V. \& Buckley, J.F. 2005. Teaching Queer English Language Arts. Journal of Adolescent \& Adult Literacy 48(3): 202-212.

Blackburn, M. and Smith, J. 2010. Moving Beyond the Inclusion of LGBT-Themed Literature in English Language Arts Classrooms: Interrogating Heteronormativity and Exploring Intersectionality. Journal of Adolescent and Adult Literacy 53(8): 625-634.

Britzman, D. and Gilbert, J. 2004. What Will Have Been Said About Gayness in Teacher Education. Teaching Education 15(1): 81-96.

Britzman, D. 1995. Is there a Queer Pedagogy? Or, Stop Reading Straight. Educational Theory 45(2): 151-165.

Butler, J. 1993. Bodies that Matter: On the Discursive Limits of Sex. New York and London: Routledge.

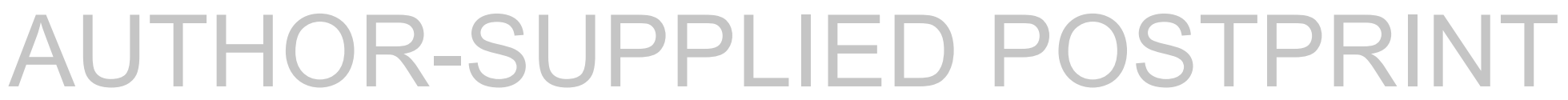


Butler, J. 1990. Gender Trouble: Feminism and the Subversion of Identity. New York and London: Routledge.

Butler, J. 2004. Undoing Gender. New York and London: Routledge.

Clark, C. 2010. Preparing LGBTQ-allies and Combating Homophobia in a US Teacher Education Program. Teaching and Teacher Education 26(3): 704-713.

Cherland, M. R. 1996. Private Practices: Girls Reading Fiction and Constructing Identity. Taylor and Francis.

Dutro, E. 2001. 'But that's a girls' book'!: Exploring Gender Boundaries in Children's Reading Practices. The Reading Teacher 55(4): 376-384.

Foucault, M. 1980. Introduction to Herculine Barbin: Being the Recently Discovered Memoirs of a Nineteenth-century French Hermaphrodite. New York, NY: Pantheon Books.

Fox, C. 2007. From Transaction to Transformation: (En)Countering White Heteronormativity in "Safe Spaces". College English 69(5): 496-511.

Gilbert, J. 2004. Literature as Sex Education. Changing English 11(2): 233-241.

Gilbert, M. 2009. Defeating Bigenderism: Changing Gender Assumptions in the Twenty-First Century. Hypathia 24(3): 93-112.

Hermann-Wilmarth, J. 2010. More than Book Talks: Preservice Teacher Dialogue after Reading Gay and Lesbian Children's Literature. Language Arts 87(3): 188-198.

Hermann-Wilmarth, J. and Ryan, C. 2013. Interrupting the Single Story: LGBT Issues in the Language Arts Classroom. Language Arts 90(3): 226-231.

Jakobsen , J. R. 1998. Queer is? Queer Does? Normativity and the Problem of Resistance. GLQ: A Journal of Lesbian and Gay Studies 4(4): 511-536.

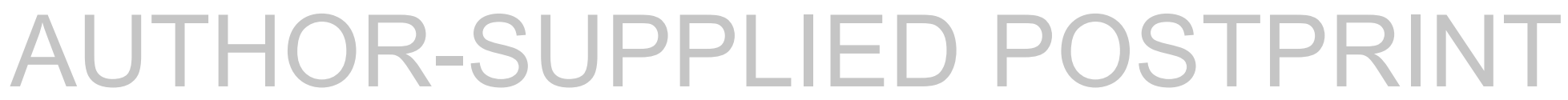


Krywanczyk, L. (n.d.) Queering Public School Pedagogy as a First-Year Teacher. Radical Teacher 79: 27-34.

Larrabee, T. and Morehead, P. 2010. Addressing LGB Issues in Teacher Education. Issues in Teacher Education 19(2): 37-52.

Lewis, C. 1999. Literacy Practices as Social Acts: Power, Status and Cultural Norms in the Classroom. Mahwah: NJ: Lawrence Erlbaum Associates.

Lovaas, K. E., Elia, J. P., and Yep, G. A. 2006.Shifting Ground(s). Journal of Homosexuality 52(1-2): $1-18$.

Macintosh, L. 2007. Does Anyone Have a Band-Aid? Anti-Homophobia Discourses and Pedagogical Impossibilities. Educational Studies 41(1): 33-43.

McNeil, T. 2013. Sex, Education, and the Promotion of Heteronormativity. Sexualities 16: 826846.

Mayo, Jr. J. B. 2013. Critical Pedagogy Enacted in the Gay-Straight Alliance: New Possibilities for a Third Space in Teacher Development. Educational Researcher 42(5): 266-275.

Miller, sj, Burns, L. D., and Johnson, T. S. 2013. Generation BULLIED 2.0: Prevention and Intervention Strategies for Our Most Vulnerable Students. Peter Lang.

Moje, E. B., and MuQaribu, M. 2003. Literacy and Sexual Identity. Journal of Adolescent and Adult Literacy 47(3): 204-208.

Parent, M., DeBlaere, C., and Moradi, B. 2013. Approaches to Research on Intersectionality: Perspectives on Gender, LGBT, and Racial/Ethnic Identities. Sex Roles 68(11): 639-645.

Pascoe, C. J. 2007. Dude, You're a Fag. University of California Press.

Payne, E. and Smith, J. 2012. Safety, Celebration, and Risk: Educator Responses to LGBTQ Professional Development. Teaching Education 23(3): 265-285. 
Piontek, T. 2006. Queering Gay and Lesbian Studies. University of Illinois Press.

Puchner, L. and Klein, N. 2011. The Right Time and Place? Middle School Language Arts Teachers Talk About Not Talking About Sexual Orientation. Equity and Excellence in Education 44(2): 233-248.

Ryan, C. L. and Hermann-Wilmarth, J. M. 2013. Already on the Shelf: Queer Readings of Award-Winning Children's Literature. Journal of Literacy Research 45: 142-172.

Schieble, M. 2012. A Critical Discourse Analysis of Teachers' Views on LGBT Literature. Discourse: Studies in the Cultural Politics of Education 33(2): 207.222.

Smolkin, L. B. and Young, C. A. 2011. Missing Mirrors, Missing Window: Children's Literature Textbooks and LGBT Topics. Language Arts 88(3): 217-235.

Sykes, H. 2011. Hetero- and Homo-Normativity: Critical Literacy, Citizenship Education and Queer Theory. Curriculum Inquiry 41(4): 419-432.

Thein, A. H. 2013. Language Arts Teachers' Resistance to Teaching LGBT Literature and Issues. Language Arts 90(3): 169-180.

Thein, A. H., and Kedley, K. E. (in preparation). Out of the Closet and All Grown Up: Problematizing Normative Narratives of Coming-out and Coming-of-age in Young Adult Literature. In Carlson, D. L., \& Linville, (Eds.), Beyond Borders: Queer Eros and Ethos (Ethics) in LGBTQ Young Adult Literature. Peter Lang.

Thorne, B. 1993. Gender Play: Girls and Boys in School. Rutgers University Press.

Thorne, B., and Luria, Z. 1986. Sexuality and Gender in Children's Daily Worlds. Social Problems 33(3): 176-190.

Vavrus, M. 2009. Sexuality, Schooling, and Teacher Identity Formation: A Critical Pedagogy T- for Teacher Education. Teaching and Teacher Education 25: 383-390. 
Vetter, A. 2010. 'Cause I'm a G': Identity Work of a Lesbian Teen in Language Arts. Journal of Adolescent and Adult Literacy 54(2): 98-108.

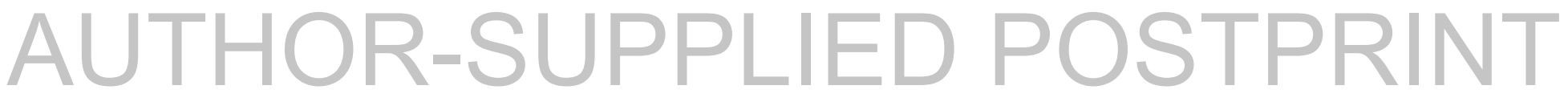

